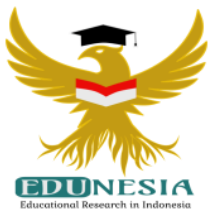

\title{
The Effectiveness of Human Resource Development Management in Efforts to Improve The Quality of Education in SD Negeri 90 Ogan Komering Ulu
}

\author{
Dauzar1; Happy Fitria2; Alhadi Yan Putra ${ }^{3}$ \\ 1,2,3 Department of Education Management, Universitas PGRI Palembang, Indonesia \\ ${ }^{1}$ Corresponding Email: dauzarspdi@gmail.com, Phone Number: 0813 xxxx xxxx
}

Article History:

Received: Mar 19, 2021

Revised: May 07, 2021

Accepted: May 22, 2021

Online First: Jun 01, 2021

\section{Keywords:}

Human Resources,

Management, Quality of

Education.

Kata Kunci:

Manajemen, Mutu Pendidikan, Sumber Daya Manusia.

\section{How to cite:}

Dauzar, D., Fitria, H., \& Putra, A.Y. (2021). The Effectiveness of Human Resource Development Management in Efforts to Improve The Quality of Education in SD Negeri 90 Ogan Komering Ulu. Edunesia: Jurnal Ilmiah Pendidikan, 2 (2): 534-550

This is an open access article under the CC-BY-NC-ND license

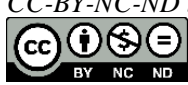

\begin{abstract}
This study aims to determine the effectiveness of human resource development management to increase quality at SD Negeri 90 Ogan Komering Hulu (OKU). This research is a qualitative research with qualitative descriptive approach. The data obtained were collected through observation, interview and documentation techniques. The results showed that the human resource development steps carried out at SD Negeri 90 OKU were carried out in 7 steps, namely compiling programs, determining needs, determining targets, determining programs, identifying learning principles, program implementation and evaluation of program implementation. Human resource management at SD Negeri $90 \mathrm{OKU}$, both in terms of quality improvement, implementation, supporting factors and the quality of education have been running optimally.
\end{abstract}

Abstrak: Penelitian ini bertujuan untuk mengetahui efektivitas manajemen pengembangan sumber daya manusia dalam upaya peningkatan mutu di SD Negeri 90 Ogan Komering Ulu (OKU). Penelitian ini merupakan penelitian kualitatif dengan pendekatan descriptive kualitatif. Data yang diperoleh dikumpulkan melalui teknik observasi, wawancara dan dokumentasi. Hasil penelitian menunjukkan bahwa Langkah pengembangan sumber daya manusia yang dilaksanakan di SD Negeri 90 OKU dilakukan dengan 7 langkah yaitu menyusun program, penentuan kebutuhan, penentuan sasaran, penetapan program, identifikasi prinsip belajar, pelaksanaan program dan penilaian pelaksanaan program.manajemen sumber daya manusia di SD Negeri 90 OKU baik itu dalam peningkatan mutu, pelaksanaan, faktor pendukung dan mutu pendidikan sudah berjalan dengan optimal. 


\section{A. Introduction}

Education is basically a process carried out to improve the quality of themselves in students. Self-quality is related to the character building factors in humans. This is the focus of the implementation of education. Ideally educational institutions function to foster and prepare students who are knowledgeable, technological, highly skilled and at the same time have faith and good deeds, within the framework of realizing the ideal function of education in schools in improving the quality of human resources, the education system must always orientate itself to answer the needs and challenges that arise. appears in society as a logical consequence of change. To achieve this goal, the role of educational institutions is at the forefront of taking its role. The role of primary schools is very decisive in the character building process of students, this is because elementary schools are educational institutions that become the initial foundation in shaping the character of students.

Human resource needs are also an important consideration in producing effective resources. How the process of recruiting educators must have certain requirements in order to be empowered as much as possible. This is done with the intention of meeting the needs of the institution and influencing human resource behavior at work.

In this case, efforts to improve and advance national development, education is a process of intellectualizing the life of the nation which is also a means to develop the whole Indonesian people. The success of National development is also greatly influenced by the quality of its human resources, both from the point of view of decision makers, policy makers, thinkers and planners, even to technical implementers and development supervisors.

The implementation of education, improving the quality of school personnel, especially teachers and the application of human resource management must be carried out so that the implementation of education programs designed by schools can run effectively and efficiently, in order to improve the quality of education to be better and more competitive. However, in fact, the application of the human resource management model has not been implemented optimally, so that school management has not been able to produce quality educators according to the needs and specifications of existing schools. For example in planning, not all schools have made or implemented programs and human resource plans that are neatly arranged so that these programs and plans can be used as guidelines in following up on the needs of the teachers needed (Riduan, 2000).

According to Masram and Mu'ah (2015) in his book states that human resources are an integrated ability of thought and physical power possessed by individuals. Meanwhile, Mukminin et al in their book (2019) states that human resources are everyone who works and contributes to an organization or institution. From these two opinions it can be understood that human resources are the potential that a person has in himself to contribute to an organizational and institutional environment. This ability is a potential that can be used to develop a more advanced and developing organization or institution. Furthermore, Mukminin et al (2019) provides a definition of Human Resources Management as an activity that includes the withdrawal, selection, development, maintenance, and use of human resources to achieve both individual and organizational goals.

Efforts to instill the character of these students need comprehensive educational management in educational institutions. The main management of school management is how to prepare adequate human resources. The implementation of human resource management in an effort to improve the quality of education is a very important issue to be explored, because the success or failure of educational institutions is largely influenced by 
the management of educational institutions. In this context it is explained that the human resources of educators and education personnel are the spearheads and need to be developed properly.

Furthermore, in recruiting teachers, especially teachers who teach in private schools. The recruitment of teachers is not in accordance with the implementation of good management and there are still elements of likes and dislikes, nepotism and lack of attention to the quality of teachers who are truly in accordance with the best level of standards.

Human resource development is carried out in an effort to improve education quality. Human resource management in question is what managerial efforts are made by the school in order to improve the performance of existing resources according to their portion and are implemented as optimally as possible. One indicator of improving the quality of education is improving the performance of existing resources optimally and in accordance with educational goals. The foregoing is also in line with the notion of education quality itself, namely the ability of educational institutions to utilize educational resources to improve learning abilities as optimally as possible (Suryadi \& Tilar, 2004).

The progress and decline of education is not caused by the curriculum but can also be caused by the quality of human resources in the educational institution. The principal as the policy holder at the educational institution level is responsible for preparing adequate human resources to provide maximum service to the community (Rosyadi \& Pardjono, 2015). The principal must master and be able to take policies and decisions that facilitate and improve the quality of education through the preparation of professional human resources.

Directly the principal is closely related to the sustainability of teaching and learning activities. In the process, the principal must be close to teachers and to students. One of the principal management roles which is very important is to compile the management of human resources both for teaching and other education personnel.

Improving the quality of education is a process that is integrated with the process of improving the quality of human resources itself. Realizing the importance of the process of improving the quality of human resources, the government together with the private sector have together and continue to strive to realize this mandate through various efforts to develop higher quality education, including through the development and improvement of curriculum and evaluation systems, improvement of educational facilities, development and procurement. teaching materials, as well as providing education and training for teachers. However, these government efforts have not been meaningful enough to improve the quality of education. For this reason, human resource management needs to be done more effectively and efficiently. This aims to determine the extent to which the educational process goes according to the plan that has been made, to find out how optimal the performance of all related components, especially regarding teacher performance, what obstacles are faced and improve the quality of all components in order to achieve educational goals and improve the quality of education in 90 Ogan Komering Ulu Elementary School.

\section{B. Method}

This research is a qualitative research, namely research procedures that produce descriptive data in the form of speech or writing and behavior that can be observed from the people itself (Furhan, 1992). Through qualitative research, it is hoped that a deep understanding and interpretation of the meaning and relevant facts can be obtained. This 
research includes field research, namely research directly plunging into a predetermined location (Furhan, 1992). The approach used in this research is a qualitative approach.

This study is to determine the implementation of human resource management in improving the quality of education in SDN 90 OKU Simpang Empat Village, Lengkiti District. With descriptive analysis, the assessment is directed to find the position, strength, meaning and relationship between documents, the impact and positive and negative consequences of the implementation of human resource management in improving the quality of education in SDN 90 OKU Simpang Empat Village, Lengkiti District. The qualitative approach seeks to understand and interpret a meaning of human behavior interaction events in certain situations according to their own perspective.

Proposes five characteristics of qualitative research, 1 . Having a natural background as a direct source. 2. Humans as research tools or instruments. 3. Analytical descriptive in nature. 4 . More concerned with the process than the results alone. 5. Inductively analyze data. Data were obtained collected through techniques observation, interviews and documentation.

\section{Result and Discussion}

In this discussion, the researcher explained descriptively the data from the research results at SD Negeri 90 OKU. Based on the stages of the theoretical framework, then the researcher analyzes the data to find common ground.

\section{Planning for Human Resource Development at SD Negeri $90 \mathrm{OKU}$}

Based on the results of the research by using interviews, the author can conclude that the principal in planning human resource development, there are several findings, namely human resource first, planning at SD Negeri 90 OKU is carried out through analysis of factors that cause changes in the workforce that occur, this is conducted through an annual evaluation which is held at the beginning of the school year. Second, compiling a plan to determine what personnel needs and what criteria are needed by SD Negeri 90 OKU. Third, conduct an analysis of internal resources, especially in terms of budgets as a result of human resource development. Fourth, determine the main targets to be achieved in the development of human resources at SD Negeri 90 OKU. Fifth, in planning human resource development SD Negeri 90 OKU determines superior programs that require the development and or addition of human resources. In the context of human resource management for schools, planning is the process of determining future human resource needs based on changes that occur and the supply of personnel in schools (Hariandja, 2000).

Based on the findings of the research conducted by the author on the management of human resource development in SD Negeri 90 OKU as mentioned above. Broadly speaking, this is in accordance with what was conveyed by Happy Fitria who stated that the success of a management is inseparable from the management principles which are the foundations and values of management itself. Principles in management should be flexible in the sense that it needs to be considered according to special conditions and changing situations (Fitria \& Nugraha, 2019). 
Furthermore, these findings are also in line with the steps in management related to planning conveyed by Hariandja in his book which states that first, analyzing several factors causing changes in human resource needs for the future. Second, forecasting human resource needs. Third, determining future human resource needs. Fourth, analysis of the availability of human resources, and fifth, program determination and implementation (Hariandja, 2000).

The analysis of factors causing changes in the workforce carried out by SD Negeri 90 OKU is to determine whether the number of workers is sufficient, insufficient or excessive, whether there are workers who will retire, transfer and so on. This is in accordance with what was conveyed by Hariandja, which stated that changes in the organizational workforce are natural and will happen, such as the need for new workers as a result of employees who retire, resign, terminate employment, transfer, die. and others (Hariandja, 2000). After analyzing various factors that influence or cause changes in human resource needs, the next step taken by SD Negeri 90 OKU is to prepare a plan to determine the needs for any workforce and what criteria and criteria the school needs are adjusted to the qualifications of the candidates. applicants who will be recruited later.

Determining the types and criteria for the required personnel is carried out jointly by involving school managers to provide input in determining the need for human resources needed. The results of this determination will be submitted to the district education office and / or local government. This is to provide input on the need for human resources to be provided through the recruitment of civil servants or opening honorary channels. The steps taken by the management of SD Negeri 90 OKU are conducting an internal analysis before carrying out and determining the implementation of the Human Resources procurement program in accordance with Efendi's view which states that the internal sources in question are employees within the school organization who can be promoted, transferred to fill vacant positions, or current employee profiles that reflect the ability of the school (Hariandja, 2000).

The purpose of this analysis is to predict the formation of personnel in schools related to the presence or absence of personnel who can and are able to cover needs by assigning new assignments to these personnel. However, if this cannot be found inside the school internally, then the next activity is to recruit from outside the school with the school management pattern submitting a request for new personnel to the Ogan Komering Ulu Regency government. If it turns out that an urgent time is needed and the OKU Regency government (Education Office) has not been able to meet the needs of teachers and staff needed by the school, then the step taken is the implementation of the planning program for the development of Educator Resources and Education Personnel implemented to recruit teachers and honorary staff by school management.

According to researchers, the planning efforts made by school management towards the needs of teachers and employees have several positive sides, personnel First, SD Negeri $90 \mathrm{OKU}$, although as a public institution, but in terms of procurement, SD Negeri 90 OKU is given the opportunity by the government (Education Office). to propose and determine 
the criteria for the personnel needed by the school. Second, even though the government does not immediately fulfill the realization of the workforce applications, SD Negeri 90 OKU can still make it happen through other planned programs related to the need for personnel through the recruitment of educators and employees with private status to become nonpermanent school employees. Third, from the human resource planning that has been compiled, it is certain that SD Negeri 90 OKU will find it easier to get personnel who are in accordance with the qualifications and specifications needed by the school through the recruitment of honorary staff.

Based on the description above, it can be understood that the development of human resources for educators and educational personnel at SD Negeri 90 OKU is carried out in the following steps:

\section{a. Planning for projections of human resource requirements}

The process of developing human resources for educators and education personnel at SD Negeri 90 OKU is prepared for long, medium and short term programs and is generally programmed at the beginning of the learning year with various considerations related to needs, facilities, implementation and budget. OKU 90 Elementary School in preparing human resource development programs for educators and education personnel is carried out in several steps, including:

1) Performance Analysis

2) Needs Analysis

3) Resource Analysis

\section{b. Determination of Needs}

In determining / analyzing needs, it is supported by several factors, including:

1) Internal factors

a) The number of educators at SD Negeri 90 OKU.

b) Educational qualifications for educators and education personnel at SD Negeri 90 OKU.

c) Suitability of diplomas with subjects.

d) Understanding about the 2013 curriculum.

2) Internal Factors

a) The competence of educators and education personnel at SD Negeri 90 OKU includes pedagogical competence, personality, social and skills.

b) The average teaching load of educators at SD Negeri 90 OKU.

c) Facilities for self-development at SD Negeri 90 OKU.

d) Welfare of educators and staff at SD Negeri 90 OKU. 


\section{c. Goal Setting}

Determination of targets as one of the steps to carry out development is carried out at SD Negeri 90 OKU with the aim of being a benchmark to determine the success or failure of the development program as well as material in an effort to determine the next steps such as program content and development methods to be used.

The target of the teaching and educational staff development program is to improve the technical, theoretical and moral capacities of educators and educational personnel in accordance with the needs of jobs or positions through existing development tools. So from this explanation it can be concluded that the goal of developing teacher resources and education personnel is to achieve the vision, mission and goals of education in schools.

\section{d. Program Determination}

The determination of the development program for Educator Resources and Education Personnel at SD Negeri 90 OKU is determined by two factors, namely the analysis of determining the needs and targets to be achieved as much as possible. Determining the program by taking decisions with due regard to various sides. This is as mentioned by Bukman Lian in his journal, which states that the decision-making process carried out by the principal is carried out with the stages of observation, data collection, planning and identifying problems related to education in schools (Lian, 2017).

\section{a. Identification of Learning Principles}

OKU 90 Public Elementary School in identifying learning principles is intended as a measure of whether or not learning principles are applied in the development program. By identifying learning principles, development will work well because of the use of appropriate learning principles. Good learning principles used for human resource development programs for educators and education personnel are participation, repetition, relevance, transfer and feedback.

The development of human resources for educators and education personnel at SD Negeri 90 OKU in relation to the principles of learning is very helpful for developing human resources. The human resources of an institution can be assessed as developing. It can also be seen from the learning process that is conducive, active, creative and innovative. It can be concluded that identifying development principles requires several things, including targets, policies, procedures, budgets, participants, curriculum and implementation time.

\section{b. Program Implementation}

The implementation of the human resource development program at SD Negeri 90 OKU is actually carried out situational, with an emphasis on calculating needs and interests, for example MGMP, Curriculum Workshop at the beginning of each school year during school holidays, including training, performance appraisal or supervision by a team of supervisors. 


\section{c. Program Implementation Assessment}

The implementation of a development program can be said to be successful if in the development participant there is a transformation process such as increasing the ability to carry out tasks, changes in work behavior, changes in attitudes and work ethics. In implementing the program to obtain good results, an assessment of a program is needed to determine the results of the program that was carried out successfully or not. For this reason, SD Negeri 90 OKU when conducting programs related to development, especially the development of human resources for educators and educational personnel, then the end of the implementation of the development program an assessment is held to find out the results obtained from the program.

Based on the explanation above, it can be concluded that SD Negeri 90 OKU in developing human resources for educators and education personnel is carried out in several steps, including programming, determining needs, determining targets, determining programs, identifying learning principles, implementing programs and evaluating program implementation.

\section{Implementation of Human Resources Development for educators and education personnel SD Negeri $90 \mathrm{OKU}$}

As the author has previously explained, the development of human resources for educators and education personnel is a complex process and involves various components that are incorporated in educational institutions (schools) which are interrelated with one another. The involvement of all these stakeholders will provide a policy that can accommodate all the interests that exist in the school. Therefore, in the process of implementing the development of teaching resources and education personnel, it does not only require skills, but also must understand the various factors that influence it. In this connection, it is necessary to make various efforts to improve the quality of educators and education personnel in schools.

\section{a) Steps in the implementation of human resource development at SD Negeri $90 \mathrm{OKU}$}

The implementation of the development of human resources for educators and education personnel at SD Negeri 90 OKU is carried out in several steps, including:

1) Developing program

A good and integrated program that is integrated with one another is arranged in programs that are short, medium and long term. Implementation in a sustainable manner and adapted to existing conditions will be able to provide a good, integrated and integrated program / planning relating to long, medium and short term planning. flexible program implementation and evaluation of human resource development programs for educators and education personnel and there are follow-ups. Potential and supporting factors as well as various possibilities that can be pursued in the human resource development program for educators and education personnel. 
2) Determination of Needs

Determination of needs carried out at SD Negeri 90 OKU is determined on the basis of a needs analysis for the present and the future and besides that it is also adjusted according to the budget. The budget that must be provided to finance development activities is a burden for schools. Therefore, in order for the provision of the budget to be truly accountable, it is necessary to first guarantee that the development activity is really needed.

\section{3) Determination of Targets}

Targeting as one of the steps to carry out development is carried out at SD Negeri 90 OKU with the aim of being a benchmark for determining the success or failure of the development program and as material in an effort to determine the next steps such as program content and development methods to be used.

Clarity of targets has benefits for development programs even though it has little feedback for those who manage human resources, both educators and education personnel, both about the program and its participants.

\section{4) Determination of the Program}

The determination of the human resource development program for educators and education personnel at the OKU 90 Public Elementary School is determined by two factors, namely the results of the analysis of determining the needs and targets to be achieved as much as possible.

In the development program, it must be clear what you want to achieve, one of the goals is to teach certain skills, which are generally new skills to carry out their duties properly, such as development carried out for learning preparation for the new academic year, including seminars, workshops, training related to the curriculum or preparation of the preparation of learning tools. Another goal that is no less important than program setting is a change in attitude and behavior in carrying out tasks.

\section{5) Identification of Learning}

Principles in OKU 90 Public Elementary Schools in identifying learning principles aimed at measuring the appropriateness of the learning principles applied in the development program. By identifying learning principles, development will work well because of the use of appropriate learning principles. Good learning principles used for human resource development programs for educators and education personnel are participation, repetition, relevance, transfer and feedback.

Related to participation in learning principles can affect the progress of the learning process more quickly and the results of this learning will last a long time. The benefit of the repetition learning principle is to repeat the learning that has been followed so that it will be stored in the brain, so that the learning material does not disappear from the brain, it needs to be repeated. After there is repetition, the next action is relevance, because with the relevance of learning activities it can take place more effectively if the materials used have 
certain relevance. After the material used is relevant, the next action is diversion, transfer from the real theory then transferred to the practice of the theory, and the last principle in learning is feedback, through feedback students will be able to find out the purpose of the learning process then students can use it in life so that the learning process can develop its potential.

The development of human resources for educators and education personnel at SD Negeri 90 OKU in relation to the principle of learning is very helpful for developing human resources. The human resources of an institution can be assessed as developing. It can also be seen from the learning process that is conducive, active, creative and innovative. Thus, with the principle of learning for an educator and educators, it can increase and develop their competence in relation to changes in attitudes, behavior and implementation of tasks with professional.

6) Program Implementation

The implementation of the human resource development program at SD Negeri 90 OKU is actually carried out situational, with an emphasis on calculating needs and interests, for example MGMP, Curriculum Workshop at the beginning of the school year during school holidays, including training, performance assessment or supervision by the principal or supervisor team.

\section{7) Assessment of Program Implementation}

The implementation of a development program can be said to be successful if a development participant occurs in a process of transformation, such as an increase in the ability to carry out tasks, changes in work behavior, changes in attitudes and work ethics. In implementing the program to obtain good results, an assessment of a program is needed to determine the results of the program that was carried out successfully or not.

Based on the explanation above, it can be concluded that the 90 OKU Public Elementary Schools in developing human resources for educators and education personnel are carried out in several steps, including programming, determining needs, determining targets, determining programs, identifying learning principles, implementing programs and evaluating program implementation.

\section{b) Methods of Development of Human Resources for Educators and Education Personnel}

In developing human resources for educators and education personnel at SD Negeri $90 \mathrm{OKU}$, there are two methods used, namely participation in education and training programs, in this case there are several types of programs, including: seminars, workshops, debriefing, pre-service, school authorities. who sent a delegation, then continued studies (continuing education to a higher level of education, especially for those interested). As for the development of internal school coaching, through various media, first, the daily program delivered by the principal to all elements of the workforce briefly every morning before the 
entrance bell, second, a forum for educators from several schools in one district that has a program of activities that discuss problems relating to official duties. Activities that have been running so far are that all elements of workforce are classified according to the field of study in turn. Third, MGMP (Subject Teachers' Deliberation), this activity is also called peer discussion guided by supervisors, this activity consists of all elementary schools both public and private in one district and even one province. Fourth: K3S (Working Group for Principals) activities that consists of school principals, both at the district and provincial levels.

\section{a. On The Job Training}

1) Job Rotation

Rotation involves moving participants from one job to another. Sometimes from one placement to another are planned on the basis of learning objectives. Position rotation can also be used as a new experience for educators and education personnel to increase professionalism.

It can be concluded that job rotation is very beneficial for educators and education personnel because participants will get a broad picture of various types of work, develop cooperation between employees, facilitate adjustment to the work environment.

\section{2) Training}

Training must be linked to improving organizational performance. This is most effective when the performance consulting approach is used. Performance consulting is the process by which a trainer (internal and external to the organization) and a customer.

There are several reasons why SD Negeri 90 OKU pays attention to increasing the competence of educators through training. First, the need of educators for new knowledge and skills, Second, educators must understand the learning process, students and understand the importance of various experiences and knowledge with others, Third, educators are prepared to be able to face education at present and in the future. Based on the research data, it is revealed that the training program is planned, the training program plan starts at the beginning of the school year and at the time of compiling the work program, and has been presented at work meetings. We also ask for input from all parties related to how appropriate and appropriate training is needed for all educators and education personnel.

\section{3) Guidance / Counseling}

Guidance / counseling is carried out in a way that participants must carry out tasks guided by senior officials / experts. Counseling is effective if the exercises are individualized and participants learn to do their work directly. 
4) Job Instructor Training

To improve the professionalism of educators and education personnel at SD Negeri $90 \mathrm{OKU}$, held several instructor exercises for several educators or education personnel to attend job instructor training then some of these people became instructors for educators as a whole.

\section{5) Demonstration and Examples}

To improve competence as an educator and educational staff of SD Negeri 90 OKU in facing the 2013 curriculum, conduct demonstrations on how to do learning using the LCD, so that the learning process is not boring, and this can develop the skills of educators in the learning process with facilities that is not separate.

It can be concluded that with this method the trainer must give an example or demonstrate how to do work / how to work a tool or machine. It is very effective because participants get theory and practice directly so that it facilitates the transfer of lessons besides this method also does not require separate facilities.

\section{6) Temporary Assignments}

In the context of developing human resources for educators and education personnel at SD Negeri $90 \mathrm{OKU}$, the head of the madrasah gives temporary assignments to several educators and education personnel according to the need to carry out certain tasks within a predetermined time, for example the head of the madrasah gives assignments For educators to become mentors in the context of the students 'training stage, automatically the educators who get the assignment will guide students while on the way and as mentors in the framework of writing students' scientific papers from the results of the stady tour.

\section{b. Off The Job Training}

1) Course

Courses are services for learning citizens in the form of knowledge, skills, mental attitudes, expertise, and skills that can be used to improve the quality of life and become provisions for earning a living and can be used to continue to a higher level of education in time the short one.

\section{2) Education}

The development of human resources for educators and education personnel at SD Negeri 90 OKU is carried out in formal and informal ways. Formal development is carried out by means of educators and education personnel assigned to participate in education and training both carried out by organizations and those carried out by educational institutions. Informal development is carried out on the basis of desire and on one's own efforts. OKU 90 Public Elementary School provides flexibility and appreciation to educators and education 
personnel to continue their education in order to develop their abilities so that they can work professionally and better.

\section{Factors for the development of human resources for educators and educational personnel}

The development of human resources for educators and education personnel at the 90 OKU Public Elementary Schools is strongly influenced by several factors, among others,

1) Personality and high dedication determine the success of educators and education personnel in carrying out their duties which is reflected in their attitudes and actions in fostering and guiding students.

2) Professional educators and education personnel are very important because their duties and roles are not only to provide scientific information but to form attitudes and souls that can survive in the era of hypercompetence.

3) The teaching ability factor of educators and educational staff is a reflection of the mastery of educators and education staff over their competence.

4) The factors of relationship and communication that occur in the work environment provide support for the smoothness of the duties of educators and education personnel in schools.

5) The factors of relationship with the community, the role of educators and education personnel in supporting relations activities school with the community can increase people's understanding of the goals and targets that the school wants to achieve.

6) Discipline factor, a job will reap results that satisfy all parties if educators and education personnel are able to obey the signs determined through the application of a disciplined attitude in carrying out their duties.

7) The level of welfare factor, provides appropriate incentives as a form of improving the level of welfare of educators and education personnel in order to prevent educators and education personnel from truancy due to looking for extras outside to meet the needs of life.

8) A conducive work climate factor provides hope for educators and education personnel to work more quietly in accordance with school goals.

From some of the explanations above related to the development of human resources for educators at the 90 OKU Public Elementary Schools, always try their best to improve and maximize the quality of educators. The activities carried out are 1) carrying out training activities, workshops, orientation and seminars on education or sending teachers as participants in these activities, whether carried out by the ministry of religion or other agencies or agencies. 2) providing direction and guidance in every monthly meeting to teachers, 3) monitoring and evaluating the implementation of the duties of educators and education personnel, both in the implementation of teaching duties and supervision in terms of the level of discipline of educators and educational staff. 
The development of human resources for educators and education personnel at the OKU 90 Public Elementary School also aims to develop several competencies that must be possessed by an educator and educational staff, including:

1) Development of Pedagogical Competencies.

The development of competencies is related to the ability of educators to manage student learning which includes understanding participants. students, planning, evaluating, developing students and designing students to actualize the various potentials they have by means of planning related to the preparation of learning administration so that when learning activities begin, all administration is completed and ready to concentrate on the learning process.

Development of 90 OKU Public Elementary Schools in developing pedagogical competences of educators by arranging learning tools or learning administration at the beginning of the learning year which begins with training first during semester breaks.

2) Development of professional

Competence of 90 OKU Public Elementary Schools in developing human resources for educators and educational staff in order to achieve a goal related to improving professional competence, the OKU 90 Public Elementary Schools conduct supervision or assessment which is carried out every mid-semester so that it is done twice in one semester.

The purpose of developing the competence of educators at the OKU 90 Public Elementary School is that educators can understand and apply the foundation of education both philosophically and logically, understand and apply learning theory according to the level of behavior development of students, be able to handle subjects or fields of study assigned to them, understand and can apply appropriate teaching methods, in essence being able to carry out an active, creative, innovative and fun learning process.

\section{3) Development of Social Competence}

Development of social competence is related to the ability of educators as part of society to communicate and socialize effectively with students, all educators, education staff, parents, guardians of students and the surrounding community.

4) Development of Personality Competencies

The development of personality competencies is related to the ability of a personality that is stable, stable, mature, wise and dignified to become role models for students and have noble character.

\section{Improving the Quality of Education in SD Negeri $90 \mathrm{OKU}$}

Based on the results of research with the interview method that the author has done in terms of improving the quality of education at SD Negeri 90 OKU, it can be explained 
that the effectiveness of increasing teaching resources and educational staff will produce professional teachers and education personnel. Professional teachers will be able to produce quality quality learning which in the end will produce maximum quality education. As stated by Bukman Lian in his research which stated that the expected quality of learning is not only an increase in academic achievement in quantity but can be seen as a condition, condition, appearance or performance shown by educators in educational units in achieving the learning objectives that have been set, interacting with the environment and satisfying students (Lian, 2020).

The quality of education is a measure of the school in describing the quality of the school. the quality of education can be improved through the availability of adequate facilities and infrastructure for the learning process with a variety of learning materials that are in accordance with the times, improving the quality of human resources and technological renewal. The school work program is prepared based on a SWOT analysis in each unit that is tailored to the goals / objectives of the school.

The quality of infrastructure owned by schools has improved a lot, due to the implementation of computerized systems and IT-based facilities. Based on the number of facilities and infrastructure, it is still inadequate. In line with this, Fitria's research results at SMA 9 Palembang which stated that the importance of management in managing facilities and infrastructure, in order to create infrastructure that can function optimally. The school principal as the leader in the school has implemented an administrative function to fix the existing infrastructure in the school starting from planning, organizing, distribution, to accountability functions (Fitria \& Nugraha, 2019).

Schools create a monitoring and evaluation system to measure customer satisfaction both in terms of infrastructure and educational services and services provided.

To improve the quality of students, schools apply varied learning methods such as changing the learning style from teacher centered focus to learning / student centered focus applying the concept of team teaching, and creating animated learning modules to improve student absorption for difficult subjects. Meanwhile, to increase the quantity of students, schools carry out many promotions and school image activities so that the name of the school is better known by the wider community.

Utilizing the school committee as a participating body by holding evaluation meetings. The school committee has a strategic role in helping to improve the quality of education in educational units. This is in line with the results of research conducted by Happy Fitria that the school committee is an independent body that accommodates community participation in the context of improving the quality, equity and efficiency of education management in schools (Fitria, 2020). The involvement of the school committee in an effort to implement an evaluation program that is continuous in nature with a pattern every end of the month and there will be a joint evaluation at the end of the semester and the end of the school year. 


\section{Conclusion}

Based on the results of the discussion and analysis by the author, the authors conclude the results of all data analysis obtained through interviews and documentation as well as field observations about the Effectiveness of Human Resource Development Management in Efforts to Improve the Quality of Education at SD Negeri 90 Ogan Komering Ulu.

1. Development of Human Resources for Educators and Education Personnel at SD Negeri 90 OKU.

The steps for developing human resources for educators and education personnel carried out at SD Negeri 90 OKU are carried out in seven steps, namely compiling development programs / planning, determining needs, determining targets, determining programs, identifying learning principles, implementing programs and evaluating program implementation.

Furthermore, the human resource development method used is to use two methods, namely on the job training which includes job rotation, training, guidance / counseling, and off the job training which includes courses, education, workshops, seminars, MGMP, comparative studies.

2. Factors for the development of human resources for educators and education personnel at SD Negeri 90 OKU.

The development factors are 1) personality and high dedication, 2) professional educators and education personnel, 3) teaching ability of educators and education personnel, 4) relations and communication, 5) community relations, 6) discipline, 7) welfare level, 8 ) A conducive working climate

\section{References}

Fitria, H., \& Nugraha, A. (2019). Manajemen Sarana dan Prasarana dalam Meningkatkan Proses Pembelajaran. Prosiding Seminar Nasional Pendidikan. Program Pascasarjana Universitas PGRI Palembang. 12 Januari 2019. p. 58-65.

Fitria, H., Roberi., \& Fitriani. (2020). Pengaruh Supervisi Kepala Sekolah dan Peran Komite Sekolah Terhadap Kinerja Guru. Jurnal Al-Qiyam. Volume 1, Nomor : 2, Desember 2020. p. 11-20.

Furhan, A. (1992). Pengantar Metode Penelitian Kualitatif. Surabaya: Usaha Nasional.

Hariandja, M.T.E. (2000). Manajemen Sumber Daya Manusia, Jakarta: Grasindo

Lian, B. (2017). Proses Pengambilan Keputusan Kepala Sekolah Terhadap Peningkatan Kinerja Guru SMP. JMKS : Jurnal Manajemen Kepemimpinan dan Supervisi Pendidikan. Program Pascasarjana Universitas PGRI Palembang. Vol. 2 No. 1 Januari-Juni 2017. p. $87-96$

Lian, B., \& Yenni. (2020). Peran Instructional Leadership Kepala Sekolah untuk Meningkatkan Profesionalisme Guru. Journal of Education Research. Vol. 1 No:3, 2020 p. 295-300. 
Masram dan Mu'ah. (2015). Manajemen Sumber Daya Manusia, Sidoarjo: Zifatama.

Riduan. (2000). Manajemen Pendidikan, Bandung: Alfabeta.

Rosyadi, Y.I., \& Pardjono. (2015). Peran Kepala Sekolah Sebagai Manajer Dalam Meningkatkan Mutu Pendidikan di SMP 1 Cilawu Garut. Jurnal Akuntabilitas Manajemen Pendidikan, 3 (1), pp. 124-133. https://doi.org/10.21831/amp.v3i1.6276

Suryadi., \& Tilaar. (2004). Manajemen Pendidikan di Sekolah, Jakarta: Rineka Cipta. 